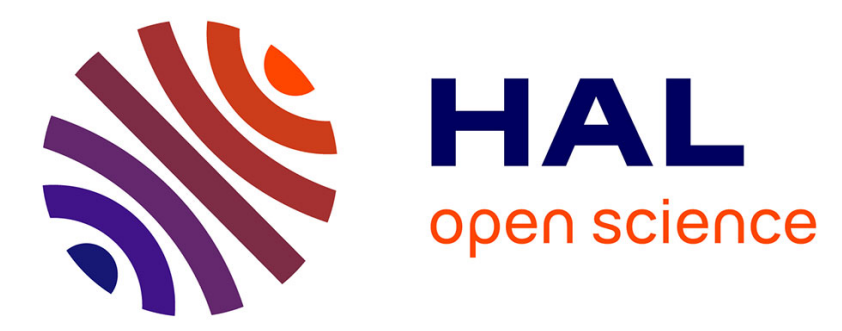

\title{
Mixed-ligand complexes of yttrium-90 dialkyldithiocarbamates with 1,10-phenanthroline as a possible agent for therapy of hepatocellular carcinoma.
}

A. Lopez, Nicolas Noiret, E. Garin, Nicolas Lepareur

\section{- To cite this version:}

A. Lopez, Nicolas Noiret, E. Garin, Nicolas Lepareur. Mixed-ligand complexes of yttrium-90 dialkyldithiocarbamates with 1,10-phenanthroline as a possible agent for therapy of hepatocellular carcinoma.. Applied Radiation and Isotopes, 2014, 94, pp.241-246. 10.1016/j.apradiso.2014.08.015 . hal-01069619

\section{HAL Id: hal-01069619 https://hal.science/hal-01069619}

Submitted on 8 Oct 2014

HAL is a multi-disciplinary open access archive for the deposit and dissemination of scientific research documents, whether they are published or not. The documents may come from teaching and research institutions in France or abroad, or from public or private research centers.
L'archive ouverte pluridisciplinaire HAL, est destinée au dépôt et à la diffusion de documents scientifiques de niveau recherche, publiés ou non, émanant des établissements d'enseignement et de recherche français ou étrangers, des laboratoires publics ou privés. 
Mixed-ligand complexes of yttrium-90 dialkyldithiocarbamates with 1,10phenanthroline as a possible agent for therapy of hepatocellular carcinoma

\author{
A. Lopez ${ }^{\mathrm{a}, \mathrm{b}}$, N. Noiret ${ }^{\mathrm{b}, \mathrm{c}}$, E. Garin ${ }^{\mathrm{a}, \mathrm{c}}$, N. Lepareur ${ }^{\mathrm{a}, \mathrm{c},{ }^{*}}$ \\ ${ }^{a}$ Centre Eugène Marquis, INSERM UMR-S 991, Avenue de la Bataille Flandres-Dunkerque, \\ CS 44229, F-35042 Rennes, France. \\ ${ }^{\mathrm{b}}$ ENSCR, CNRS UMR 6226, 11, Allée de Beaulieu, CS 50837, F-35708 Rennes, France. \\ ${ }^{\mathrm{c}}$ Université Européenne de Bretagne, F-35000 Rennes, France
}

*Corresponding author: Tel.: +33-2-99-25-31-44; Fax: +33-2-99-25-32-60;

E-mail: n.lepareur@rennes.unicancer.fr (N. Lepareur)

\begin{abstract}
Yttrium-90 is a radioelement which has found wide use in targeted radionuclide therapy because of its attractive physical and chemical properties. Radioembolisation of hepatocellular carcinoma with radiolabelled Lipiodol is a method of choice. We have synthesised a series of alkyldithiocarbamate yttrium complexes, easily extracted into Lipiodol due to their high lipophilicity. Among the prepared series, a new radioconjugate, which is stable over an extended period of time, has been prepared, and could represent a potential treatment procedure for hepatocellular carcinoma.
\end{abstract}

Keywords: Dithiocarbamate; 1,10-phenanthroline; Hepatocellular carcinoma; Lipiodol; Radionuclide therapy; Yttrium-90 


\section{1- Introduction}

Hepatocellular carcinoma (HCC), the most common form of primary liver cancers, is the fifth most common tumour worldwide, and even ranks third in terms of mortality (Ferlay et al., 2010; Jemal et al., 2011). For the vast majority of patients not eligible to curative treatments, such as resection or transplantation, there is a wide range of palliative treatments which can be proposed, among which are chemoembolisation and radioembolisation with Lipiodol or microspheres (Venook, 1994; Thomas and Zhu, 2005; Liapi and Geschwind, 2010; Lencioni, 2010; Raoul et al., 2010). Lipiodol is an oily medium which has shown to be selectively retained in tumour when administered intra-arterially (Chou et al., 1995). Lipiodol has been labelled with iodine-131 (Liebster and Kocandrle, 1964; Raoul et al., 1986), rhenium-188 (Lepareur et al., 2008), yttrium-90 (Wang et al., 1996b; Yu et al., 2003), and radiolanthanides (Das et al., 2009; Subramanian et al., 2010). Yttrium-90 (pure beta-emitter, $\mathrm{E} \beta_{\max }=2.27$ $\mathrm{MeV}, \mathrm{t}_{1 / 2}=64 \mathrm{~h}$, max tissue penetration $=12 \mathrm{~mm}$ ) has ideal properties for targeted radiotherapy, and has found wide use in peptide receptor radionuclide therapy (Goffredo et al., 2011), radioimmunotherapy (Sharkey et al., 2010) and radioembolisation (Salem and Hunter, 2006). It has been suggested as a suitable isotope to label Lipiodol as it should lead to a significantly reduced whole-body dose compared to ${ }^{131}$ I-Lipiodol, since more than $90 \%$ of this dose is due to the emitted gamma rays (respectively $0.02 \mathrm{rad} / \mathrm{mCi}$ compared to 1.9 $\mathrm{rad} / \mathrm{mCi}$, based on estimated dosimetry) (Madsen et al., 1988). After having successfully developed radiolabelled Lipiodol with rhenium-188 (Lepareur et al., 2004; Lepareur et al., 2012), we decided to develop a new labelling of Lipiodol with yttrium-90 for the treatment of HCC, as a complementary tool in the treatment armamentarium. A series of heteroligand yttrium dialkyldithiocarbamate complexes with 1,10-phenanthroline has been prepared, and their suitability to label Lipiodol has been investigated. 


\section{2- Experimental}

\subsection{Materials and Methods}

Yttrium-90 was obtained from IBA as yttrium chloride in $\mathrm{HCl} 0.04 \mathrm{M}$ (Ytracis, CIS bio International/IBA, Gif-sur-Yvette, France). Lipiodol was obtained from Guerbet (Villepinte, France). 1,10-Phenanthroline was purchased from Acros (Illkirch, France). Sodium diethyldithiocarbamate was purchased from Aldrich (Saint Quentin Fallavier, France). Other dithiocarbamates were synthesised according to the literature from the corresponding secondary amines and carbon disulfide. Briefly, in a $100 \mathrm{~mL}$ round-bottom flask, under nitrogen, $14 \mathrm{mmol}$ of $N$-methylalkylamine were diluted in $30 \mathrm{~mL}$ diethyl ether. The roundbottom flask was cooled down to $-15^{\circ} \mathrm{C}$ in an ice/salt bath. $532 \mathrm{mg}(13.3 \mathrm{mmol})$ of sodium hydroxide in methanol were added under stirring. $1.1 \mathrm{~g}(14.6 \mathrm{mmol})$ of carbon disulfide were slowly added under stirring. The mixture was stirred for 30 minutes in the ice/salt bath, then at room temperature for 90 minutes. The obtained precipitate was filtered then dried under vacuum to give a white powder.

Non-radioactive compounds were characterized by ${ }^{1} \mathrm{H}$ and ${ }^{13} \mathrm{C}$ NMR recorded with a BRUKER ARX 400 (Billerica MA, USA) at 400.13 and $100.62 \mathrm{MHz}$, respectively, in $\mathrm{CDCl}_{3}$, calibrated internally to the residual solvent. ES mass analysis was done on a Shimadzu LCMS 2020 (Kyoto, Japan). Activity measurements were done in a CRC-127R well-counter (Capintec Inc., Ramsey NJ, USA). TLC analyses were done on ITLC-SG plates (Pall Life Sciences, Ann Arbor MI, USA) with methanol as mobile phase. The plates were analysed with a Perkin Elmer Cyclone Storage Phosphor Imager, using the Packard Optiquant v04.00 software. 


\subsection{Preparation of $\left[{ }^{89} Y(D E D C)_{3}(\right.$ Phen $\left.)\right]($ C1 $)$}

$\mathrm{MW}=713$

In a $20 \mathrm{~mL}$ round-bottom flask, under nitrogen, $180 \mathrm{mg}(1 \mathrm{mmol})$ of 1,10-phenanthroline, dissolved in $2 \mathrm{~mL}$ methanol, and $675 \mathrm{mg}(3 \mathrm{mmol})$ of sodium $N, N$-diethyldithiocarbamate trihydrate, dissolved in $2 \mathrm{~mL}$ methanol, are placed. $200 \mathrm{mg}(1 \mathrm{mmol})$ of yttrium chloride were dissolved in $2 \mathrm{~mL}$ methanol and were added dropwise to the ligands. The complex precipitated. The mixture was stirred for 20 minutes at room temperature then filtered, washed with methanol, and dried under vacuum to give $\mathbf{C 1}$ as white crystals (619 mg, 87 \%). ${ }^{1} \mathrm{H}$ NMR $\left(\mathrm{CDCl}_{3}\right)$ : 9.99 (dd, J = 4.9, $\left.1.5 \mathrm{~Hz}, 2 \mathrm{H}, \mathrm{H}-\mathrm{Phen}\right), 8.37$ (dd, J = 8.1, $1.6 \mathrm{~Hz}, 2 \mathrm{H}, \mathrm{H}-$ Phen), 7.85 (s, 2H, $\mathrm{H}_{4}$ ), 7.72 (dd, J = 8.1, 4.9 Hz, 2H, H-Phen), 3.83 (q, J = 7.1 Hz, 12H, $\left.\mathrm{NCH}_{2}\right), 1.12\left(\mathrm{t}, \mathrm{J}=7.1 \mathrm{~Hz}, 18 \mathrm{H}, \mathrm{CH}_{3}\right) .{ }^{13} \mathrm{C} \mathrm{NMR}\left(\mathrm{CDCl}_{3}\right): 205.8\left(\mathrm{CS}_{2}\right), 151.8$ (CH-Phen), 144,9 (C-Phen), 137.9 (CH-Phen), 129.4 (C-Phen), 126.8 (CH-Phen), 123.5 (CH-Phen), 46.1 $\left(\mathrm{NCH}_{2}\right), 12.4\left(\mathrm{CH}_{3}\right) . m / z=713.40 . \mathrm{R}_{f}(\mathrm{MeOH})=0.76$.

\subsection{Preparation of $\left[{ }^{90} Y(d t c)_{3}(\right.$ Phen $\left.)\right]$ and Lipiodol radiolabelling}

$100 \mu \mathrm{L}$ of ${ }^{90} \mathrm{YCl}_{3}$ in acetate buffer $(\mathrm{pH}=4.75)$ were added to a solution of $100 \mu \mathrm{L}$ of sodium dithiocarbamate $15.10^{-2} \mathrm{M}$ in ethanol and $100 \mu \mathrm{L}$ of phenanthroline $5.10^{-2} \mathrm{M}$ in ethanol. Several parameters such as concentration of ligands, volume and $\mathrm{pH}$ of the reaction mixture, incubation time, and temperature were varied extensively to arrive at the optimised protocol. For the preparation of ${ }^{90} \mathrm{Y}$-Lipiodol, $\left[{ }^{90} \mathrm{Y}(\mathrm{dtc})_{3}(\mathrm{Phen})\right]$ complex prepared under optimised reaction conditions was extracted in $2 \mathrm{~mL}$ Lipiodol. After vigorous shaking for 2 minutes to ensure homogeneous dispersion of the complex in Lipiodol, the phases were separated by centrifugation. Chemical identity of the radiotracer was assessed for $\left[{ }^{90} \mathrm{Y}(\mathrm{DEDC})_{3}(\mathrm{Phen})\right]$ by comparing its TLC profile in $\mathrm{MeOH}$ with that of the fully characterised analogous non- 
radioactive complex $\mathbf{C 1}$. Other dithiocarbamates tracers were assumed to have similar structures.

\subsection{Determination of complexation yield of $\left[{ }^{90} Y(d t c)_{3}(\right.$ Phen $\left.)\right]$}

The complexation yield of the $\left[{ }^{90} \mathrm{Y}(\mathrm{dtc})_{3}(\mathrm{Phen})\right]$ radiotracer prepared was determined by solvent extraction technique. $300 \mu \mathrm{L}$ of chloroform were added. The mixture was vigorously shaken, then centrifuged ( $3840 \mathrm{rpm}, 15 \mathrm{~min})$ to separate the phases. The two phases were carefully collected and counted in a well-counter. The complexation yield was determined as the organic layer activity on the total (aqueous + organic) activity.

\subsection{Determination of labelling yield of Lipiodol}

The labelling yield of Lipiodol was determined by an analogue technique. $900 \mu \mathrm{L}$ of saline and $2 \mathrm{~mL}$ of Lipiodol were added. The mixture was vigorously shaken, and then centrifuged (3840 rpm, $15 \mathrm{~min}$ ) to separate the phases. The two phases were carefully collected and counted in a well-counter. The complexation yield was determined as the Lipiodol layer activity on the total (aqueous + Lipiodol) activity.

\subsection{In vitro stability of ${ }^{90} Y$-Lipiodol}

To check the in vitro stability of ${ }^{90} \mathrm{Y}$-labelled Lipiodol, $2 \mathrm{~mL}$ of saline was added to the preparation and mixed vigorously. The mixture was allowed to settle at room temperature. $100 \mu \mathrm{L}$ of aliquots were withdrawn from both layers at different time intervals postpreparation and the associated activity was counted. The stability of the radiolabelled preparation at various time points was determined by calculating the percentage of activity associated with the lipid phase from these data. 


\section{3- Results and Discussion}

When injected through the hepatic artery, Lipiodol, an iodinated mixture of esterified poppyseed oil, is selectively trapped in tumour cells (HCC and some hepatic metastases) (Nakakuma et al., 1985). Besides, Lipiodol displays a prolonged retention within the tumour, while it is more quickly cleared from the healthy liver (Chou et al, 1995; Kan, 1996). It has thus been used for the detection of $\mathrm{HCC}$ and as a vector for chemotherapeutic drugs (Bhattacharya and Dusheiko, 1995; Dalla Palma ,1998).

When radiolabelled with iodine-131, Lipiodol has shown a high tumour-to-liver ratio, with some activity in the lungs (depending on arterioveinous shunts) and no activity in the thyroid, thus excluding iodine-131 release (Madsen et al., 1988; Raoul et al., 1988; Yoo et al., 1994). Covalently labelled Lipiodol with rhenium-188 and yttrium-90 demonstrated a biodistribution

similar to ${ }^{131}$ I-Lipiodol (Wang et al., 1996a; Wang, et al., 1996b). This approach was however disappointing, and it was demonstrated that solubilisation of a labelled lipophilic chelate into Lipiodol was a better approach (Jackson et al., 2000). To efficiently interact with Lipiodol, the radiocomplex has to be conveniently lipophilic. Other important criteria when choosing which ligands to use are ease of labelling and, as much as possible, known toxicity and compatibility for in vivo use (to facilitate acceptance for human use). One type of ligands that fits these criteria is dialkyldithiocarbamates (dtc). Lipophilicity can easily be modified by modulating the length of the alkyl chain. Several radiopharmaceutical complexes have been described with dithiocarbamates, with indium-113m (Abram et al., 1985), copper-62 (Matsumoto et al., 1990), bismuth-212 (Parks et al., 1992), technetium-99m (Pasqualini et al., 1994), and rhenium-188 (Boschi et al., 2004). Moreover, rare earth complexes with dithiocarbamates have been the subject of an abundant literature and their structures have been extensively discussed (Nief, 1998; Cotton, 2004; Hitchcock et al., 2004; Regulacio et al., 2005). Reaction of yttrium and lanthanides with dithiocarbamates can results in ternary 
neutral complexes or quaternary anionic complexes. In the first case, lanthanides favouring octa-coordinated structure, the coordination sphere of the metal is usually completed with solvents molecules, such as $\left[\mathrm{Ln}\left(\mathrm{Me}_{2} \mathrm{dtc}\right)_{3}(\mathrm{DMSO})_{2}\right](\mathrm{Ln}=\mathrm{La}, \mathrm{Pr}, \mathrm{Nd}, \mathrm{Sm}-\mathrm{Tb})(\mathrm{Su}$ et al., $1995)$ or $\left[\mathrm{Ln}\left(\mathrm{Me}_{2} \mathrm{dtc}\right)_{3}(\mathrm{THF})_{2}\right](\mathrm{Ln}=\mathrm{Ce}, \mathrm{Nd}, \mathrm{Tb})($ Hitchcock et al., 2004), or else with the addition of a neutral $\pi$-donor ligand such as 2,2 '-bipyridyl or 1,10-phenanthroline ( $\mathrm{Su}$ et al., 1996; Regulacio et al., 2008). With this additional ligand, there is an easy electron delocalisation among the large conjugate system which, as well as the rigid plane, enables a stable crystal packing, thus enhances the stability of the complex (Su et al., 1999). Mixed dithiocarbamate-phenanthroline yttrium and lanthanide complexes are easily synthesised in soft conditions, readily crystallize and are air-stable. Some may even be prepared in aqueous media (Ivanov et al., 2002). This can be advantageous for the preparation of radiotracers. On the contrary, without the neutral bidentate ligand, complexes of the $\left[\operatorname{Ln}(\mathrm{dtc})_{3}\right]$ type are unstable and hydrolyze rapidly, necessitating inert atmosphere and strongly anhydrous conditions (Brown and Holah, 1968). Therefore, 1,10-phenanthroline was chosen to complete the coordination sphere of the yttrium complexes.

Important factors for the optimal radiolabelling of the ${ }^{90} \mathrm{Y}$-radiotracer are the solvent, volume, temperature, incubation time and concentration of the components. Their effects were thus studied. Ligands with different alkyl chain lengths were also investigated. It appeared that the lower was the volume, the higher was the reaction yield. EtOH was chosen to dissolve the ligands, as it is the most compatible solvent for human injection. Concentrations of the ligands were varied from $10^{-3}$ to $10^{-1} \mathrm{M}$ - with a 3:1 ratio for dtc:Phen - to ascertain the optimum ligand concentration required for maximum complexation. It was found that $15.10^{-2}$ $\mathrm{M}$ for dithiocarbamate and $5.10^{-2} \mathrm{M}$ for 1,10-phenanthroline gave the best results. 
Concerning the $\mathrm{pH}$ of the reaction medium, a slightly acidic $\mathrm{pH}$ was found to give the best results (Figure 2). In neutral to basic $\mathrm{pH}$, yttrium chloride quickly hydrolyses to insoluble $\mathrm{Y}(\mathrm{OH})_{3}$, thus preventing the reaction to proceed correctly. When the reaction medium was too acidic, the reaction did not proceed as well, because the dithiocarbamate is under the dithiocarbamic acid form (i.e. pKa of the diethyldithiocarbamic acid/diethyldithiocarbamate couple is 3.37 (Aspila et al., 1970)) which cannot bind to the metal. The reaction thus proceeded in ammonium acetate buffer $(\mathrm{pH}=4.75)$.

Temperature and reaction time were also investigated, with the DEDC ligand, and it was demonstrated that room temperature gave the best results (Figure 3). It was not necessary to let the reaction proceed for a long time, since after 5 minutes, the yield did not improve (Figure 4). This is advantageous in radiopharmaceutical synthesis, even if, with the 64-h halflife of yttrium-90, this is not crucial. For comparison, Yu et al. (Yu et al., 2003) have chelated 8-hydroxyquinoline (oxine) with yttrium-90 to label Lipiodol. The ${ }^{90} \mathrm{Y}$-oxine complex is prepared in $30 \mathrm{~min}$ at $50^{\circ} \mathrm{C}$. As well, the covalent binding of Lipiodol and yttrium-90 via an $N, N, N^{\prime}, N^{\prime}$-tetrakis (2-benzymidazolylmethyl)-1,2-ethanediamine (EDTB) chelate (Wang et al., 1996b) necessitated a 4-hour preparation.

Several dithiocarbamates, with different chain lengths, were investigated to find the optimal complex to label Lipiodol. The optimised procedure $(\mathrm{pH}=4.75,5 \mathrm{~min}$ at room temperature) was used. There were no significant differences between two carbons (DEDC, L1) and twelve carbons, L3. All complexes were obtained in high yield. On the other hand, with the sixteen carbons alkyl chain L4 ligand, labelling yield decreased to $62.95 \pm 8.86 \%$ (Figure 5), most likely due to steric hindrance. Indeed, stability of lanthanide dithiocarbamate complexes highly relies upon steric effects of the dithiocarbamate substituent (Siddall, III and Stewart, 1970). Increasing the reaction time with $\mathbf{L} 4$ did not change the outcome. 
This trend is confirmed when labelling Lipiodol with these complexes (Figure 6). Using the long-chain L4 dithiocarbamate ligand, the labelling yield decreased to $64 \%$. This low yield was not due to poor extraction of the highly lipophilic complex, but because of the low formation of this compound, as most of the activity was free ${ }^{90} \mathrm{Y}$. Labelling yield was also somewhat lower with $\left[{ }^{90} \mathrm{Y}(\mathbf{L 1})_{3} \mathrm{Phen}\right]$ compared to $\left[{ }^{90} \mathrm{Y}(\mathbf{L} 3)_{3} \mathrm{Phen}\right]$, due to the lower lipophilicity of the complex. TLC profiles, on ITLC-SG plates in methanol, showed only one spot, thus indicating only one species in the organic phase. Comparison of TLC profiles for $\left[\mathrm{Y}(\mathrm{DEDC})_{3}(\mathrm{Phen})\right]$, both prepared at macromolecular scale (characterised by NMR and electrospray mass analysis) and at tracer level, confirmed the chemical identity of the radiotracer $\left(\mathrm{R}_{f}=0.76\right)$.

Labelling Lipiodol with $\left[{ }^{90} \mathrm{Y}(\mathrm{dtc})_{3} \mathrm{Phen}\right]$ is easy and consists more precisely in an extraction of the yttrium complex into the Lipiodol phase (Mu et al., 2007). Selective extraction was attained with 5-minute shaking at room temperature, without the need for intermediate organic solvent extraction and subsequent evaporation, as was the case for the oxine complexes, which required an extraction into dichloromethane prior to solubilisation in Lipiodol (Yu et al., 2003; Das et al., 2009; Subramanian et al., 2010).

In vitro stability has been checked in saline, over a period of 8 days (Figure 7). Here, $\left[{ }^{90} \mathrm{Y}(\mathbf{L} 1)_{3} \mathrm{Phen}\right]$ appeared to be more stable than $\left[{ }^{90} \mathrm{Y}(\mathbf{L} 3)_{3} \mathrm{Phen}\right]$. Indeed, the latter complex was more easily released from Lipiodol, this release increasing with time, while $80 \%$ of the activity remains in Lipiodol with $\left[{ }^{90} \mathrm{Y}(\mathbf{L} 1)_{3}\right.$ Phen]. 


\section{4- Conclusions}

A new method for the ${ }^{90} \mathrm{Y}$-labelling of Lipiodol has been demonstrated. Based on labelling yields and in vitro stability, $\left[{ }^{90} \mathrm{Y}(\mathrm{DEDC})_{3}(\mathrm{Phen})\right]$ seems to be the best candidate. Animal experiments are underway to check the biodistribution profile and in vivo stability of the radioconjugate. Lipiodol labelling with stronger activities (therapeutic doses) of yttrium-90 is also envisaged, to ascertain potential autoradiolysis. For this, automation of the synthesis is planned.

\section{Abbreviations}

Bipy $=2,2^{\prime}$-bipyridyl

$\mathrm{DEDC}=$ diethyldithiocarbamate

$\mathrm{dtc}=$ dithiocarbamate

$\mathrm{HCC}=$ hepatocellular carcinoma

Phen $=1,10$-phenanthroline

\section{Acknowledgments}

The authors thank Labex IRON for financial support. 


\section{References}

Abram, S., Abram, U., Spies, H., Muenze, R., 1985. Metastable indium-113 chelate complexes. I: In vitro investigations on a series of alkyl-varied dithiocarbamate complexes with metastable indium-113. Int. J. Appl. Radiat. Isot. 36, 653-656.

Aspila, K.I., Joris, S.J., Chakrabarti, C.L., 1970. Determination of the acid dissociation constant for diethyldithiocarbamic acid. Primary and secondary salt effects in the decomposition of diethyldithiocarbamic acid. J. Phys. Chem. 74, 3625-3629.

Bhattacharya, S. Dusheiko, G.M., 1995. Treatment of unresectable hepatocellular carcinoma: Targeted therapies using iodized oil. Proc. Int. Symp. Princess Takamatsu Cancer Res. Fund 25th, 253-264.

Boschi, A., Uccelli, L., Duatti, A., Colamussi, P., Cittanti, C., Filice, A., Rose, A.H., Martindale, A.A., Claringbold, P.G., Kearney, D., Galeotti, R., Turner, H.J., Giganti, M., 2004. A kit formulation for the preparation of 188Re-lipiodol: preclinical studies and preliminary therapeutic evaluation in patients with unresectable hepatocellular carcinoma. Nucl. Med. Commun. 25, 691-699.

Brown, D., Holah, D.G., 1968. N,N-Diethyldithiocarbamate complexes of certain tervalent lanthanide and actinide elements. Chem. Commun. (London) 23, 1545-1546.

Chou, F.I., Fang, K.C., Chung, C., Lui, W.Y., Chi, C.W., Liu, R.S., Chan, W.K., 1995. Lipiodol uptake and retention by human hepatoma cells. Nucl. Med. Biol. 22, 379-386.

Cotton, S., 2004. Scandium, yttrium, and the lanthanides, in: McCleverty, J. A., Meyer T. J. (Eds.), Comprehensive Coordination Chemistry II Vol. 3, Pergamon, Oxford, UK, pp. 93-188. Dalla Palma, L., 1998. Diagnostic imaging and interventional therapy of hepatocellular carcinoma. Br. J. Radiol. 71, 808-818. 
Das, T., Chakraborty, S., Sarma, H.D., Venkatesh, M., Banerjee, S., 2009. Preparation of 166Ho-oxine-lipiodol and its preliminary bioevaluation for the potential application in therapy of liver cancer. Nucl. Med. Commun. 30, 362-367.

Ferlay, J., Shin, H.R., Bray, F., Forman, D., Mathers, C., Parkin, D.M., 2010. Estimates of worldwide burden of cancer in 2008: GLOBOCAN 2008. Int. J. Cancer 127, 2893-2917.

Goffredo, V., Paradiso, A., Ranieri, G., Gadaleta, C.D., 2011. Yttrium-90 (90Y) in the principal radionuclide therapies: an efficacy correlation between peptide receptor radionuclide therapy, radioimmunotherapy and transarterial radioembolization therapy. Ten years of experience (1999-2009). Crit. Rev. Oncol. Hematol. 80, 393-410.

Hitchcock, P.B., Hulkes, A.G., Lappert, M.F., Li, Z., 2004. Cerium(III) dialkyl dithiocarbamates from $[\mathrm{Ce}\{\mathrm{N}(\mathrm{SiMe} 3) 2\} 3]$ and tetraalkylthiuram disulfides, and $\left[\mathrm{Ce}\left(\hat{\mathrm{I}}^{\circ} 2-\right.\right.$ S2CNEt2)4] from the CeIII precursor; TbIII and NdIII analogues. Dalton Trans. 1, 129-136.

Ivanov, R.A., Korsakov, I.E., Formanovskii, A.A., Paramonov, S.E., Kuz'mina, N.P., Kaul', A.R., 2002. Heteroligand Lanthanide Dialkyldithiocarbamate Complexes with 1,10Phenanthroline: A New Approach to Synthesis and Application for the Preparation of Sulfides. Russ. J. Coord. Chem. 28, 670-672.

Jackson, T.W., Kojima, M., Lambrecht, R.M., 2000. Rhenium diamino dithiol complexes. III. Lipophilic ligands for endotherapeutic radiopharmaceuticals. Aust. J. Chem. 53, 983-987.

Jemal, A., Bray, F., Center, M.M., Ferlay, J., Ward, E., Forman, D., 2011. Global cancer statistics. CA Cancer J. Clin. 61, 69-90.

Kan, Z., 1996. Dynamic study of iodized oil in the liver and blood supply to hepatic tumors. An experimental investigation in several animal species. Acta Radiol. Suppl. 408, 1-25.

Lencioni, R., 2010. Loco-regional treatment of hepatocellular carcinoma. Hepatology 52, 762-773. 
Lepareur, N., Garin, E., Noiret, N., Herry, J.Y., 2004. A kit formulation for the labelling of lipiodol with generator-produced 188Re. J. Label. Compd. Radiopharm. 47, 857-867.

Lepareur, N., Ardisson, V., Garin, E., Noiret, N., 2008. Therapy of Hepatocellular Carcinoma with Rhenium-188 Lipiodol. Curr. Radiopharm. 1, 87-92.

Lepareur, N., Ardisson, V., Noiret, N., Garin, E., 2012. 188Re-SSS/Lipiodol: development of a potential treatment for HCC from bench to bedside. Int. J. Mol. Imaging 2012, Article ID 278306.

Liapi, E., Geschwind J.F.H., 2010. Intra-arterial therapies for hepatocellular carcinoma: where do we stand? Ann. Surg. Oncol. 17, 1234-1246.

Liebster, J., Kocandrle, V., 1964. Exchange labelling of 'Lipiodol' utra fluids with iodine-131 and its intra-lymphatic administration with a fistula on the thoracic duct. Nature 203, 777-778. Madsen, M.T., Park, C.H., Thakur, M.L., 1988. Dosimetry of iodine-131 ethiodol in the treatment of hepatoma. J. Nucl. Med. 29, 1038-1044.

Matsumoto, K., Fujibayashi, Y., Konishi, J., Yokoyama, A., 1990. Radiolabeling and biodistribution of $62 \mathrm{Cu}$-dithiocarbamate--an application for the new $62 \mathrm{Zn} / 62 \mathrm{Cu}$ generator. Radioisotopes 39, 482-486.

Mu, P.Y., Jiang, X.L., Chen, J., Wang, J.C., He, Q., Zhu, Y.J., Jin, M.J., Li, F., 2007. Research on extracted 90Y with P204 in lipiodol for liver cancer. J .Radioanal. Nucl. Chem. $272,669-671$.

Nakakuma, K., Tashiro, S., Hiraoka, T., Ogata, K., Ootsuka, K., 1985. Hepatocellular carcinoma and metastatic cancer detected by iodized oil. Radiology 154, 15-17.

Nief, F., 1998. Complexes containing bonds between Group 3, lanthanide or actinide metals and non-first-row main group elements (excluding halogens). Coord. Chem. Rev. 178-180, $13-81$. 
Parks, N.J., Harris, W.R., Keen, C.L., Cooper, S.R., 1992. Coordination chemistry of the lead212/bismuth-212 nuclear transformation: Alpha-emitting radiopharmaceuticals: Final technical report. DOE/ER/61035-T1, Order No. DE92019048, 1-30.

Pasqualini, R., Duatti, A., Bellande, E., Comazzi, V., Brucato, V., Hoffschir, D., Fagret, D., Comet, M., 1994. Bis(dithiocarbamato) nitrido technetium-99m radiopharmaceuticals: a class of neutral myocardial imaging agents. J. Nucl. Med. 35, 334-341.

Raoul, J.L., Duvauferrier, R., Bourguet, P., Bretagne, J.F., Coornaert, S., Darnault, P., Deugnier, Y., Herry, J.Y., Gastard, J., 1986. L'angiographie lipiodolée au cours des carcinomes hépato-cellulaires. Apport du lipiodol marqué à l'iode 131. J. Radiol. 67, 797-801. Raoul, J.L., Bourguet, P., Bretagne, J.F., Duvauferrier, R., Coornaert, S., Darnault, P., Ramee, A., Herry, J.Y., Gastard, J., 1988. Hepatic artery injection of I-131-labeled lipiodol. Part I. Biodistribution study results in patients with hepatocellular carcinoma and liver metastases. Radiology 168, 541-545.

Raoul, J.L., Boucher, E., Rolland, Y., Garin, E., 2010. Treatment of hepatocellular carcinoma with intra-arterial injection of radionuclides. Nat. Rev. Gastroenterol. Hepatol. 7, 41-49.

Regulacio, M.D., Tomson, N., Stoll, S.L., 2005. Dithiocarbamate Precursors for Rare-Earth Sulfides. Chem. Mater. 17, 3114-3121.

Regulacio, M.D., Pablico, M.H., cay Vasquez, J., Myers, P.N., Gentry, S., Prushan, M., TamChang, S.W., Stoll, S.L., 2008. Luminescence of Ln(III) Dithiocarbamate Complexes (Ln = La, Pr, Sm, Eu, Gd, Tb, Dy). Inorg. Chem. 47, 1512-1523.

Salem, R., Hunter, R.D., 2006. Yttrium-90 microspheres for the treatment of hepatocellular carcinoma: a review. Int.J.Radiat.Oncol.Biol.Phys. 66, S83-S88.

Sharkey, R.M., Karacay, H., Goldenberg, D.M., 2010. Improving the treatment of nonHodgkin lymphoma with antibody-targeted radionuclides. Cancer 116, 1134-1145. 
Siddall, T.H., III, Stewart, W.E., 1970. Preparation and studies of magnetic and spectroscopic properties of alkylammonium lanthanide tetrakis(N,N'dialkyldithiocarbamates). J. Inorg. Nucl. Chem. 32, 1147-1158.

Su, C., Tang, N., Tan, M., Liu, W., Gan, X., Yu, K., 1995. Synthesis, spectroscopic properties and structure of bis(dimethyl sulfoxide)tris(N,N-dimethyldithiocarbamato)lanthanide(III). J. Coord. Chem. 36, 41-48.

Su, C., Tan, M., Tang, N., Gan, X., Liu, W., Wang, X., 1996. Synthesis, Structure and Spectroscopic Properties of Complexes of Rare Earth Dithiocarbamates with 2,2'-Bipyridyl and 1,10-Phenanthroline. J. Coord. Chem. 38, 207-218.

Su, C.Y., Tan, M.Y., Zhang, Z.F., Tang, N., Cai, L.P., and Xue, Q.J., 1999. Dithiocarbamate Complexes of Trivalent Lanthanides and X-Ray Crystal Structure of tris $(\mathrm{N}, \mathrm{N}-$ Diisopropyldithiocakhamato)(1,10-Phenanthroline)Neodymium(III). Syn. React. Inorg. and Met.-Org. Chem. 29, 35-51.

Subramanian, S., Das, T., Chakraborty, S., Sarma, H.D., Banerjee, S., Samuel, G., Venkatesh, M., 2010. Preparation of $177 \mathrm{Lu}-$ labeled oxine in lipiodol as a possible agent for therapy of hepatocellular carcinoma: a preliminary animal study. Cancer Biother. Radiopharm. 25, 539543.

Thomas, M.B., Zhu, A., X, 2005. Hepatocellular carcinoma: the need for progress. J. Clin. Oncol. 23, 2892-2899.

Venook, A.P., 1994. Treatment of hepatocellular carcinoma: too many options? J. Clin. Oncol. 12, 1323-1334.

Wang, S.J., Lin, W.Y., Chen, M.N., Hsieh, B.T., Shen, L.H., Tsai, Z.T., Ting, G., Knapp, F.F.J., 1996a. Biodistribution of rhenium-188 Lipiodol infused via the hepatic artery of rats with hepatic tumors. Eur. J. Nucl. Med. 23, 13-17. 
Wang, S.J., Lin, W.Y., Lui, W.Y., Chen, M.N., Tsai, Z.T., Ting, G., 1996b. Hepatic artery injection of yttrium-90-lipiodol: biodistribution in rats with hepatoma. J. Nucl. Med. 37, 332335.

Yoo, H.S., Park, C.H., Lee, J.T., Kim, K.W., Yoon, C.S., Suh, J.H., Park, C.Y., Kim, B.S., Choi, H.J., Lee, K.S., 1994. Small hepatocellular carcinoma: high dose internal radiation therapy with superselective intra-arterial injection of I-131-labeled Lipiodol. Cancer Chemother. Pharmacol. 33 Suppl, S128-S133.

Yu, J., Häfeli, U.O., Sands, M., Dong, Y., 2003. 90Y-oxine-ethiodol, a potential radiopharmaceutical for the treatment of liver cancer. Appl. Radiat. Isot. 58, 567-573. 
Figure 1: Structure of the mixed ligand yttrium complexes [Y(dtc $\left.)_{3}(\mathrm{Phen})\right]$

Figure 2: Influence of the $\mathrm{pH}$ on the radiosynthesis of $\left[{ }^{90} \mathrm{Y}(\mathbf{L} \mathbf{1})_{3} \mathrm{Phen}\right]$

Figure 3: Influence of the temperature on the radiosynthesis of $\left[{ }^{90} \mathrm{Y}(\mathbf{L 1})_{3} \mathrm{Phen}\right]$

Figure 4: Influence of the reaction time on the radiosynthesis of $\left[{ }^{90} \mathrm{Y}(\mathbf{L 1})_{3} \mathrm{Phen}\right]$

Figure 5: Influence of the alkyl chain length on the radiosynthesis (5 min, RT)

Figure 6: Influence of the alkyl chain length on the radiolabelling of Lipiodol (5 min, RT)

Figure 7: In vitro stability of the radiotracers $\left[{ }^{90} \mathrm{Y}(\mathbf{L} 1){ }_{3} \mathrm{Phen}\right]$ and $\left[{ }^{90} \mathrm{Y}(\mathbf{L} \mathbf{3}){ }_{3}\right.$ Phen $]$

Table 1: The different ligands studied for the preparation of yttrium complexes 


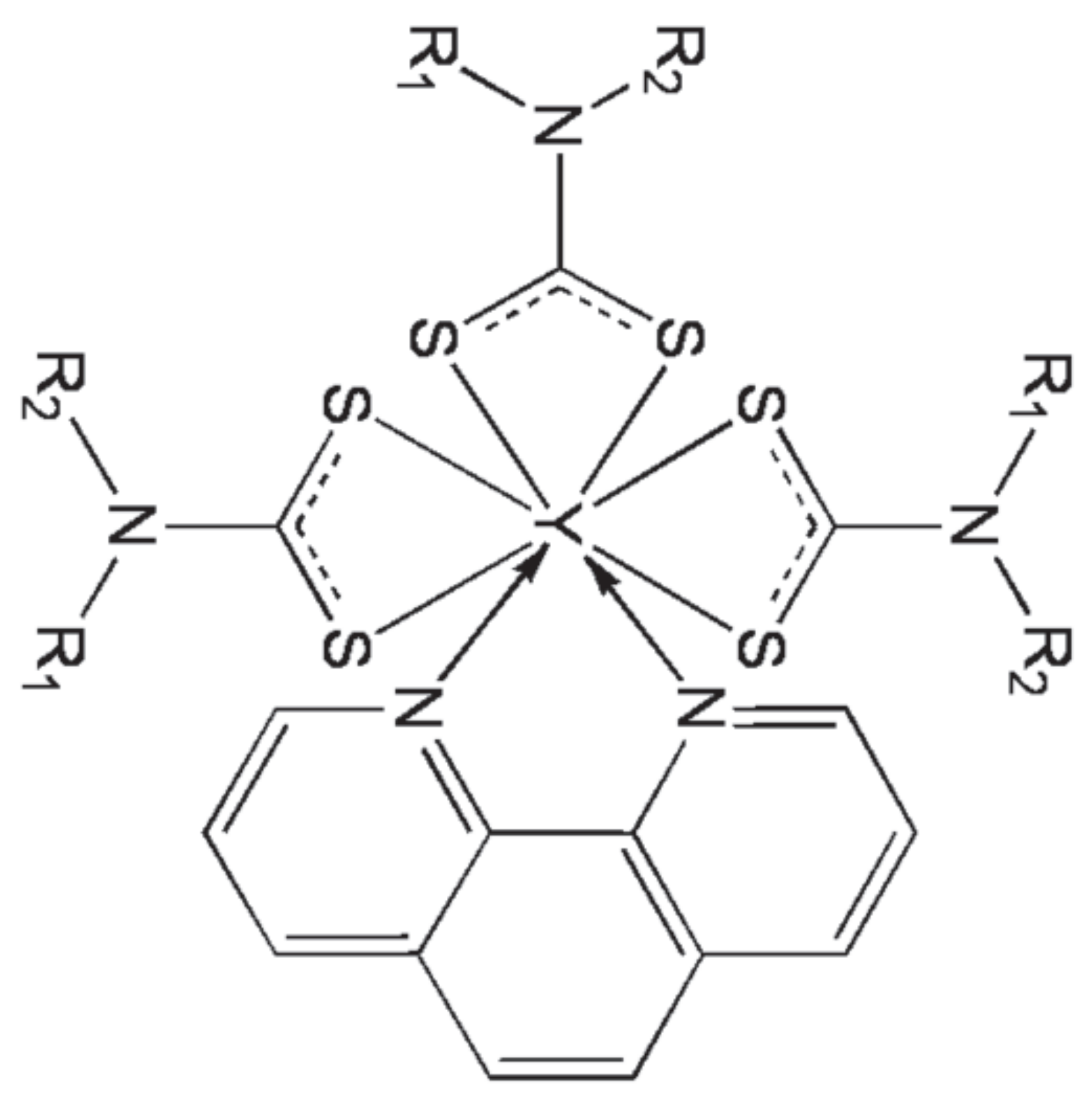


Page 1

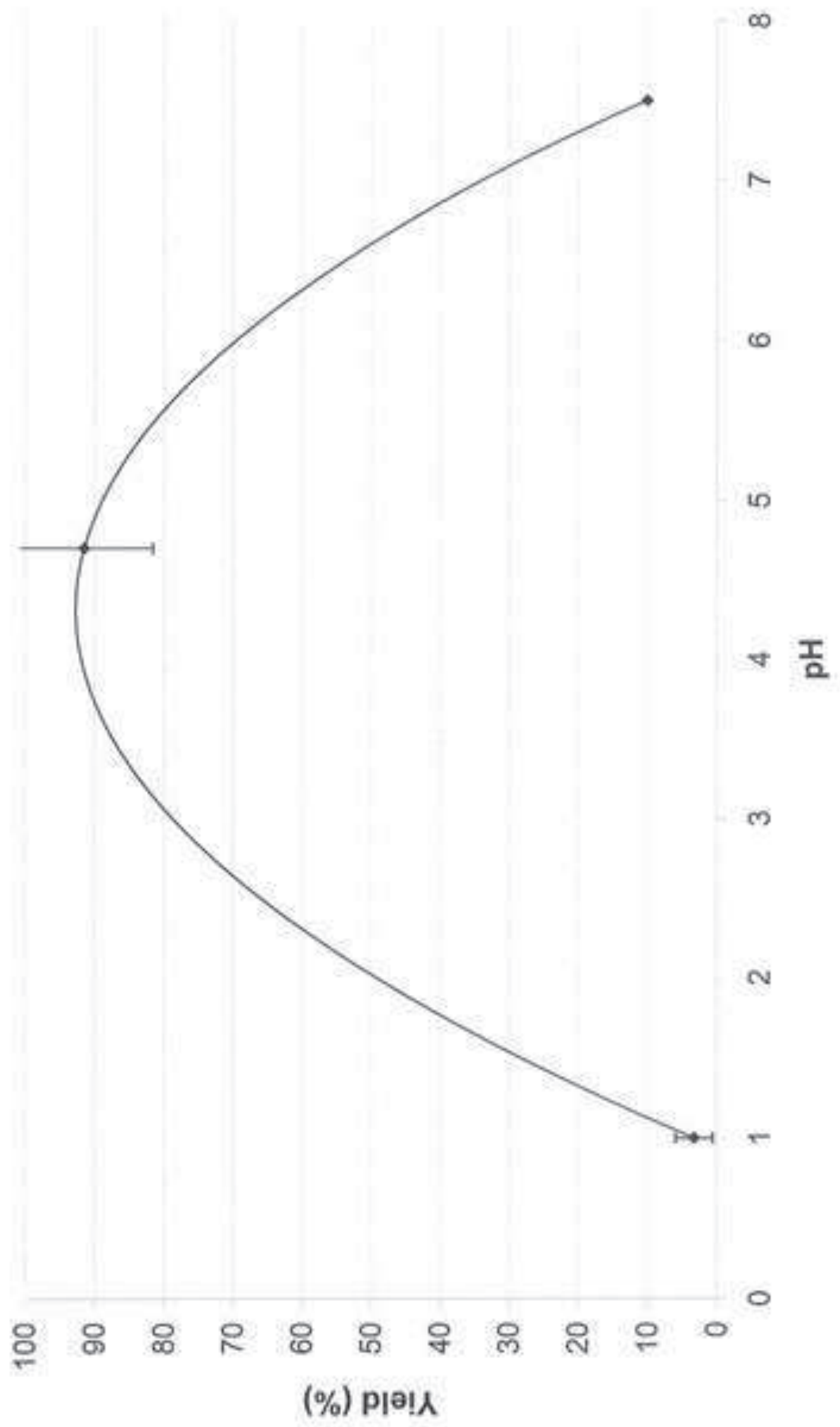


Page 1

으

요

요

ㅇ

8

유 $\frac{\widehat{U}}{5}$

웅

요

오

으

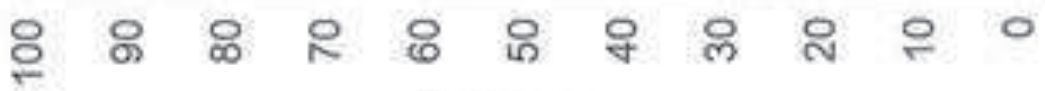

(\%) p|ə!ㅅ 
Page 1

ஜூ

요

ผ

ำ

들

으

เ)

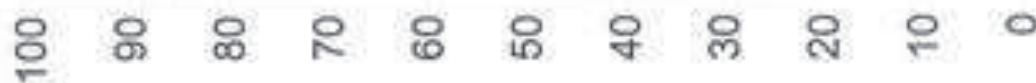

(\%) p1ㅣㅅㅅ 
Page 1

$\stackrel{\infty}{\infty}$

$\oplus$

$\stackrel{+}{\square}$

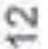

으

응

$\omega$

寸

N

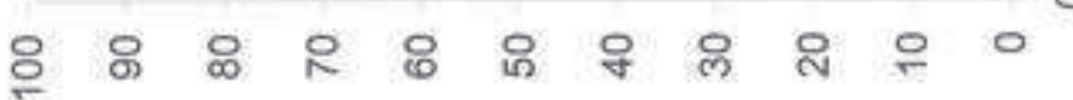

(\%) ріә!ג 
Page 1

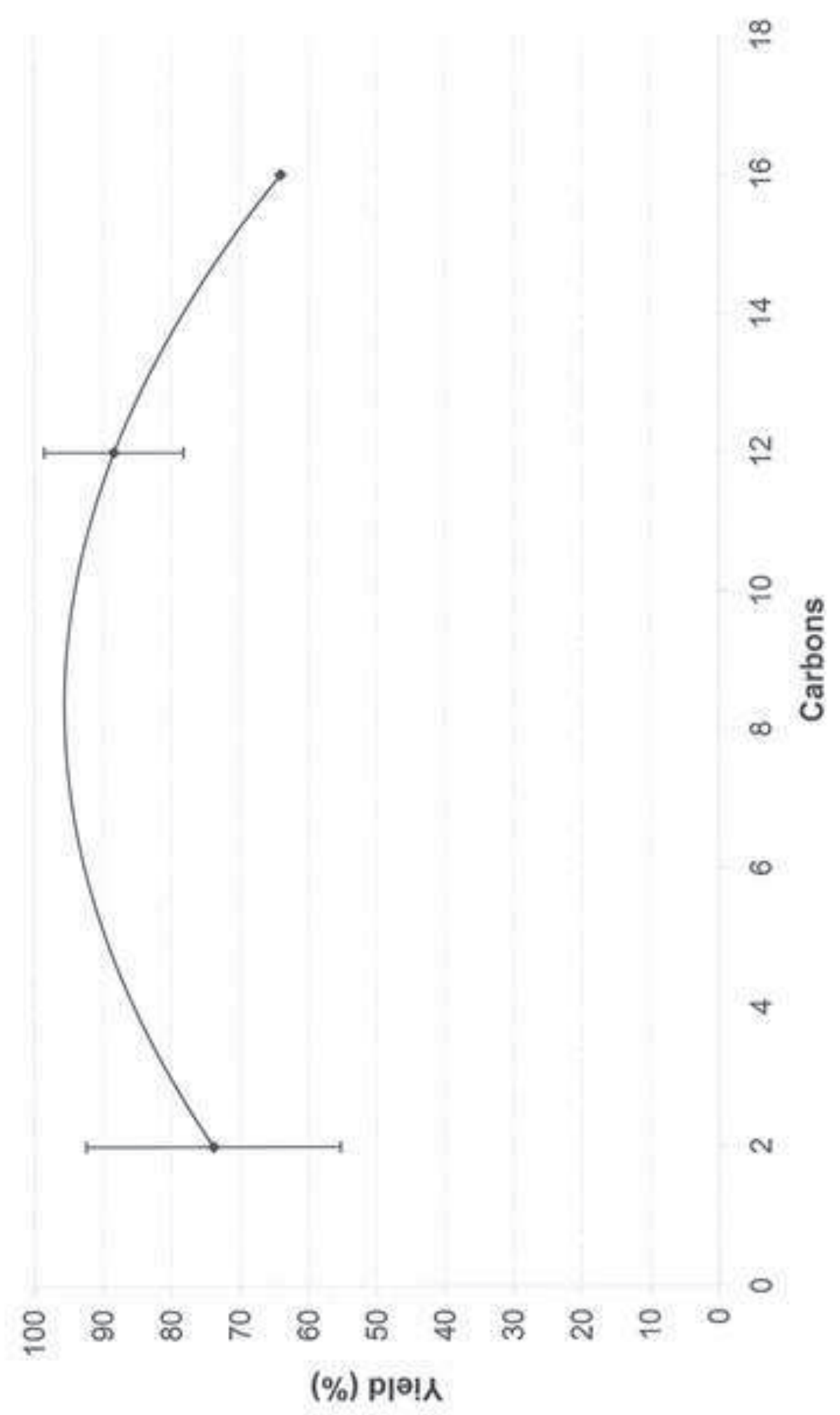


Page 1

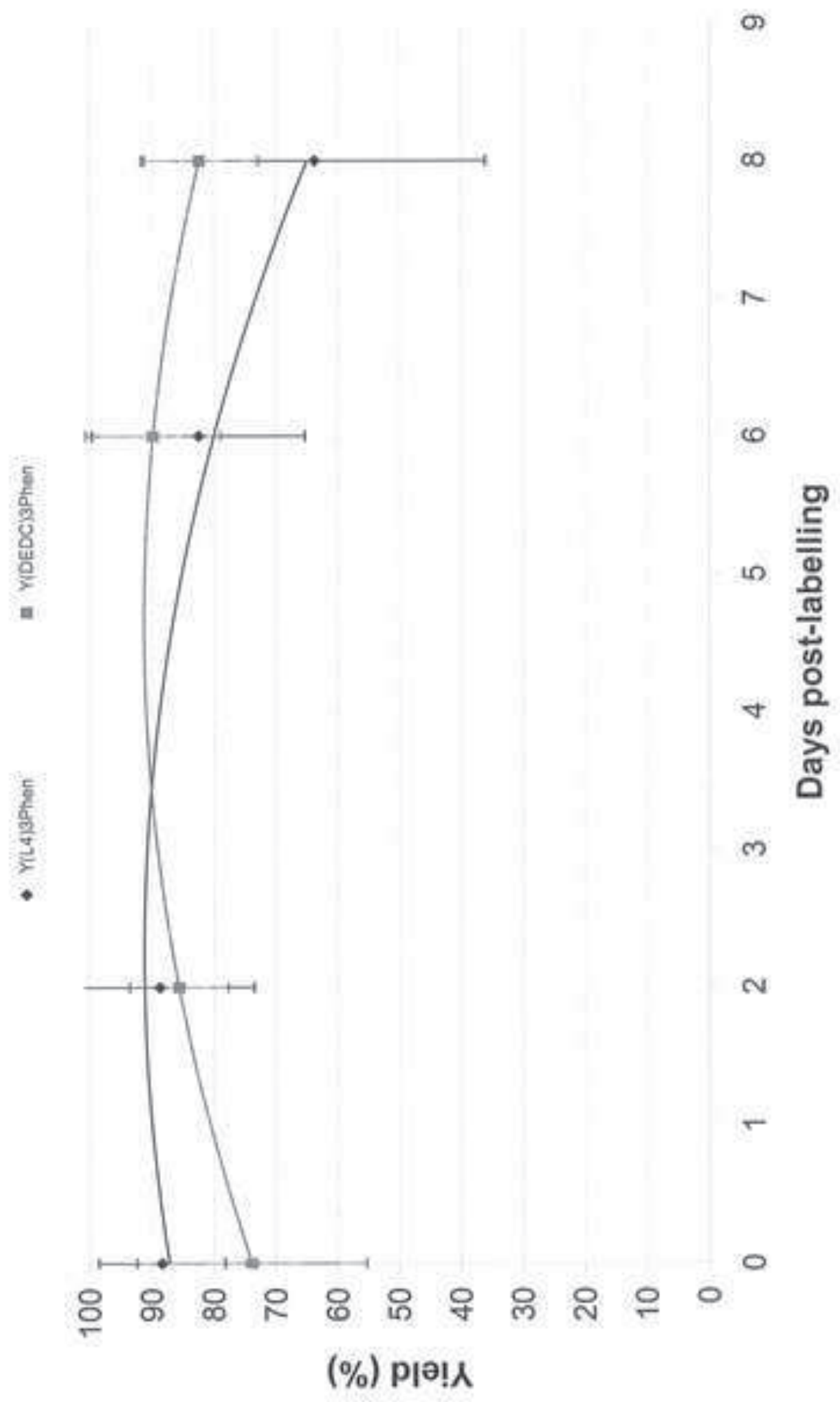




\begin{tabular}{ccc}
\hline & & \\
$\boldsymbol{R}_{\boldsymbol{1}}$ & $\mathrm{Rt}$ & \\
$\mathrm{Et}$ & $\mathrm{Re}$ & Ligand \\
$\mathrm{CH}_{3}\left(\mathrm{CH}_{2}\right)_{7}$ & $\mathrm{Me}$ & $\mathbf{L 1}$ \\
$\mathrm{CH}_{3}\left(\mathrm{CH}_{2}\right)_{11}$ & $\mathrm{RNa}$ & $\mathbf{L 2}$ \\
$\mathrm{CH}_{3}\left(\mathrm{CH}_{2}\right)_{15}$ & $\mathrm{Me}$ & $\mathbf{L 3}$ \\
\hline
\end{tabular}

